\title{
Xp11.2 Translocation
}

National Cancer Institute

\section{Source}

National Cancer Institute. Xp11.2 Translocation. NCI Thesaurus. Code C153560.

A cytogenetic abnormality that refers to any translocation involving Xp11.2 on the short arm of the $X$ chromosome. 